\title{
Lectotypification of Beilschmiedia gammieana (Lauraceae)
}

\author{
Baro D. ${ }^{1 *}$, Bawri A. ${ }^{2} \&$ S.K. Borthakur ${ }^{3}$ \\ 'Department of Botany, Tinsukia College, Tinsukia, Assam - 786 125, India \\ ${ }^{2}$ North Eastern Institute of Folk Medicine, Pasighat, Arunachal Pradesh - 791 102, India \\ ${ }^{3}$ Department of Botany, Gauhati University, Guwahati, Assam - 781 014, India \\ *E-mail: daimalupbaro@gmail.com
}

\begin{abstract}
The name Beilschmiedia gammieana King ex Hook.f. is lectotypified here.

Keywords: Lectotype, Nomenclature, Syntype Typification.
\end{abstract}

\section{Introduction}

The genus Beilschmiedia Nees (Lauraceae) is a pantropical genus, distributed in Africa, Asia, Australia, Pacific Islands, New Zealand, South and Central America with approximately 250 species (van der Werff, 2003). Nine species were recognized from India (Santapau \& Henry, 1973). During the revisionary studies of Lauraceae in Northeast India, the need for lectotypification of the name Beilschmiedia gammieana King ex Hook.f. was realised. Accordingly, after critical studies of type specimens at $\mathrm{K}$ and comparison with the protologue, the lectotypification has been done in accordance with the provisions in Art. 9.11 and 9.12 of ICN (Turland et al., 2018).

Beilschmiedia gammieana is widely distributed in India (Assam, Arunachal Pradesh and Sikkim), Bhutan and Nepal (Hooker, 1886; Giri et al., 2008; Barooah \& Ahmed, 2014). The name was first mentioned by King in Herbarium Hortus Calcuttensis and it was described by Hooker based on G. King collection and his own specimens (Hooker, 1886). In the protologue, Hooker

Received: 26.02.2020; Revised \& Accepted: 10.04.2020

Published Online: 30.06.2020 mentioned collection details as "EAST NEPAL, on the north slope of Phulloot, alt. 6000 ft., J.D.H., and Sikkim at the same elevation, King" but he did not specify any specimen as type. After scrutiny of specimens in different Indian herbaria (ASSAM, ARUN, BSHC, CAL and DD) and images (BM, E, HBG, K, LINN, NY and P), three relevant specimens were located at K. Among them, one specimen (K000768652) collected by King from Sikkim and two specimens (K000768653 and K000768654) collected by Hooker from East Nepal were mounted on a single sheet. The specimen K000768652 bearing fruits, a character important for identification of Beilschmiedia species, is designated here as the lectotype.

Beilschmiedia gammieana King ex Hook.f., Fl. Brit. India 5: 124. 1886. Lectotype (designated here): INDIA, Sikkim, Phamlet Pot, Himalaya, 05.10.1876, King 3063 (K [K000768652 digital image!]).

Fig. 1

\section{Acknowledgements}

We are grateful to the Curators of the herbaria (ASSAM, ARUN, BSHC, CAL and DD) for permission to consult the specimens and authorities of $\mathrm{K}$ for providing images of the type. We wish to thank the reviewer's for their valuable suggestions. Second author is also thankful to Science and Engineering Research Board (SERB), Government of India (PDF/2016/000264), for financial assistance. 


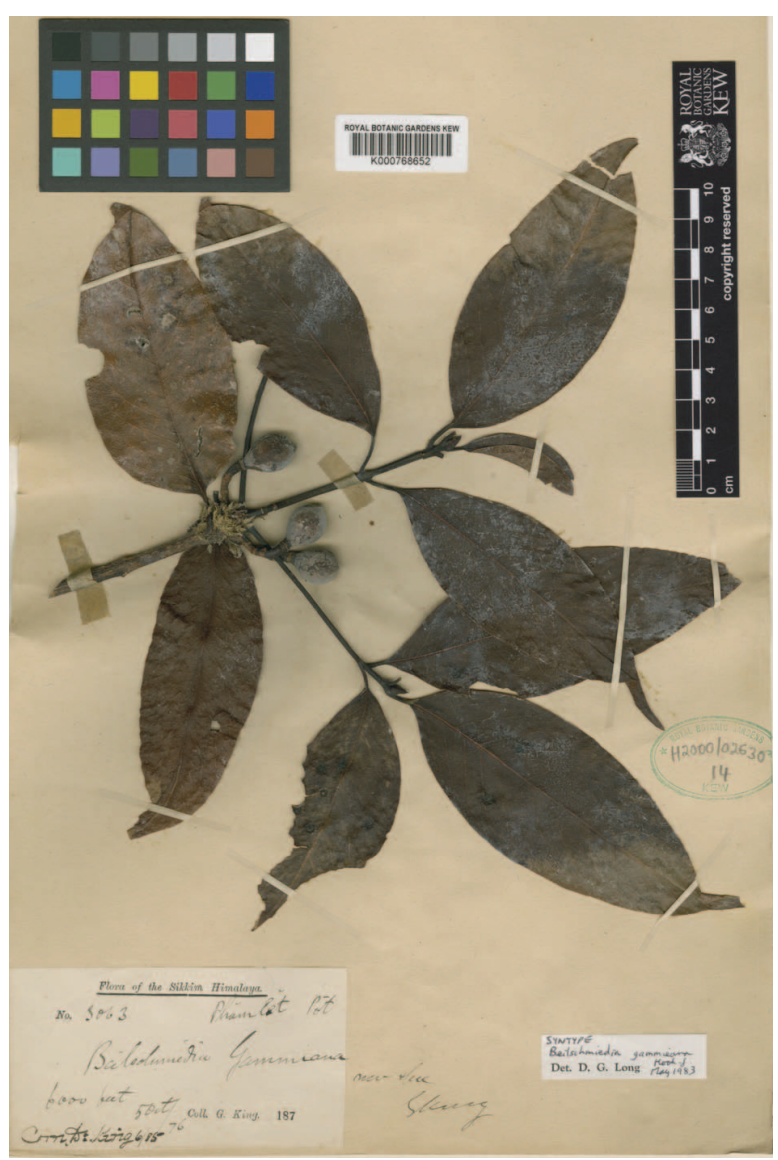

Fig. 1. Lectotype of Beilschmiedia gammieana King ex Hook.f. (K000768652). (C) The Board of Trustees for the Royal Botanic Gardens, Kew. Reproduced with permission.

\section{Literature Cited}

BAROOAH C. \& I. AHMED 2014. Plant diversity of Assam: a checklist of Angiosperms \& Gymnosperms. Assam Science Technology and Environment Council, Guwahati.

GIRI G.S., PRAMANIK A. \& H.J. CHOWDHERY 2008. Material for the flora of Arunachal Pradesh. Volume 2. (Asteraceae-Ceratophyllaceae). Botanical Survey of India, Kolkata.

HOOKER J.D. 1886. Flora of British India. Volume 5. Chenopodiaceae-Orchideae. L. Reeve \& Co., London.

SANTAPAU H. \& A.N. HENRY 1973. A dictionary of the flowering plants in India. National Institute of Science Communication, New Delhi, p. 198.

TURLAND N.J., WIERSEMA J.H., BARRIE F.R., GREUTER W., HAWKSWORTH D.L., HERENDEEN P.S., KNAPP S., KUSBER W.H., LI D.Z., MARHOLD K., MAY T.W., M NEILL J., MONRO A.M., PRADO J., PRICE M.J. \& G.F. SMITH (eds.) 2018. International Code of Nomenclature for Algae, Fungi, and Plants (Shenzhen Code) Adopted by the Nineteenth International Botanical Congress Shenzhen, China, July 2017. Regnum Vegetabile 159, Volume 38. Glashütten, Koeltz Botanical Books, Glashütten. pp. 1-254. https:// doi.org/10.12705/Code.2018

VAN DER WERFF H. 2003. A synopsis of the genus Beilschmiedia (Lauraceae) in Madagascar. Adansonia 25(1): 77-92. 